\title{
Contributed Papers
}

Seventy-seven contributed papers were selected following a blind reviewing process. The papers have been paired by subject matter and will be presented during one-hour time slots throughout the conference. The papers will be published in the conference procedings, available in June 1989. Brief descriptions of the papers are listed here for your convenience and information.

\section{READERS SERVICES}

Papers 1, Wednesday, April 5,

2:45 p.m.-3:45 p.m., Room 251

"Outcomes of Print and Online Ready Reference Searches: Summary of an Experimental Study," will report the results of a study of social science ready reference questions. W. Michael Havener, University of Oklahoma.

"Thinking Like a Searcher: Cognitive Strategy and the Search Process," will examine what searchers know and how they use this knowledge to generate search strategies. Donna D. Rubens, University of Minnesota, and Mary M. Huston, Brainerd Community College.

Papers 2, Wednesday, April 5, 3:55 p.m.-4:55 p.m., Room 251

"Design and Testing of Microcomputer Interface Software for End-User Searching," will present the results of a statistical study and features analysis based on the administration of questionnaires, transaction log analysis, and focused group interviews. William H. Mischo, University of Illinois at Urbana-Champaign.

"BRS After Dark at the University of Arizona Library," will describe the history of the fully subsidized QuickSearch service, current policies and procedures and the results of three years of experience in providing end-user online searching on a campus-wide basis. Jeanne L. Pfander, University of Arizona.

Papers 3, Thursday, April 6, 8:30 a.m.-9:30 a.m., Room 251

"Expert Systems as Interactive User Aids," will examine the development of microcomputer-based expert systems to better serve the needs of those requiring the types of information contained in reference sources. Ralph Alberico, James Madison University.

"Expert Systems: New Challenges and Opportunities," will discuss how expert systems will allow the librarian to engage in more creative activities and provide an improvement in services for users. Donald E. Riggs, Arizona State University.

\section{COLLECTION DEVELOPMENT}

\author{
Papers 4, Thursday, April 6, \\ 8:30 a.m.-9:30 a.m., Room 252
}

"Where Does the Money Go? Measuring CostEffectiveness Using a Microcomputer to Analyze Journal Use Data," will present the results of a sixmonth journal use survey. Tina Chrzastowski, University of Illinois at Urbana-Champaign.

"Circulation Patterns of Recent Imprints: Implications for the Materials Budget," will report the results of a study that compared the circulation patterns of recent imprints received on approval, and concluded that there were very few differences in circulation among the eighteen categories examined. Jane Treadwell, Texas A\&M University.

Papers 5, Thursday, April 6,

10:15 a.m.--11:15 a.m., Room 252

"Adapting an AS/RS to the Library Environment," will identify factors to consider in installing an automated storage and retrieval system (AS/RS). Douglas A. Davis, Norma S. Creaghe and Norman E. Tanis, California State University, Northridge.

"Weeding the Collection: Are Libraries Failing Their Charge?" will propose that academic libraries are discarding valuable reference materials, including those within the field of librarianship. James R. Mouw, University of Illinois at Chicago.

Papers 6, Thursday, April 6, 11:25 a.m.-12:25 p.m., Room 252

"CASSI and Collection Assessment: New Uses for an Old Tool," will discuss a project using the Chemical Abstracts Service Source Index to assess the depth of a serials collection in comparison with university libraries with strong chemistry and chemical engineering programs. Christine Johnston, University of Texas at Austin.

"Liberal Arts College Library Acquisitions: Are Past Practices Appropriate for the Future?" will maintain that because of budgets and collection size, acquisitions practices in smaller liberal arts college libraries should be directed toward items which are used rather than items for future research needs. David H. Eyman, Skidmore College.

Papers 7, Thursday, April 6, 4:10 p.m.-5:10 p.m., Room 252

"Evaluating Journals: Can Faculty Do the Job?" will examine the relationship between faculty evaluations of life science journals and charged circulation of the journals. The evidence presented indi- 


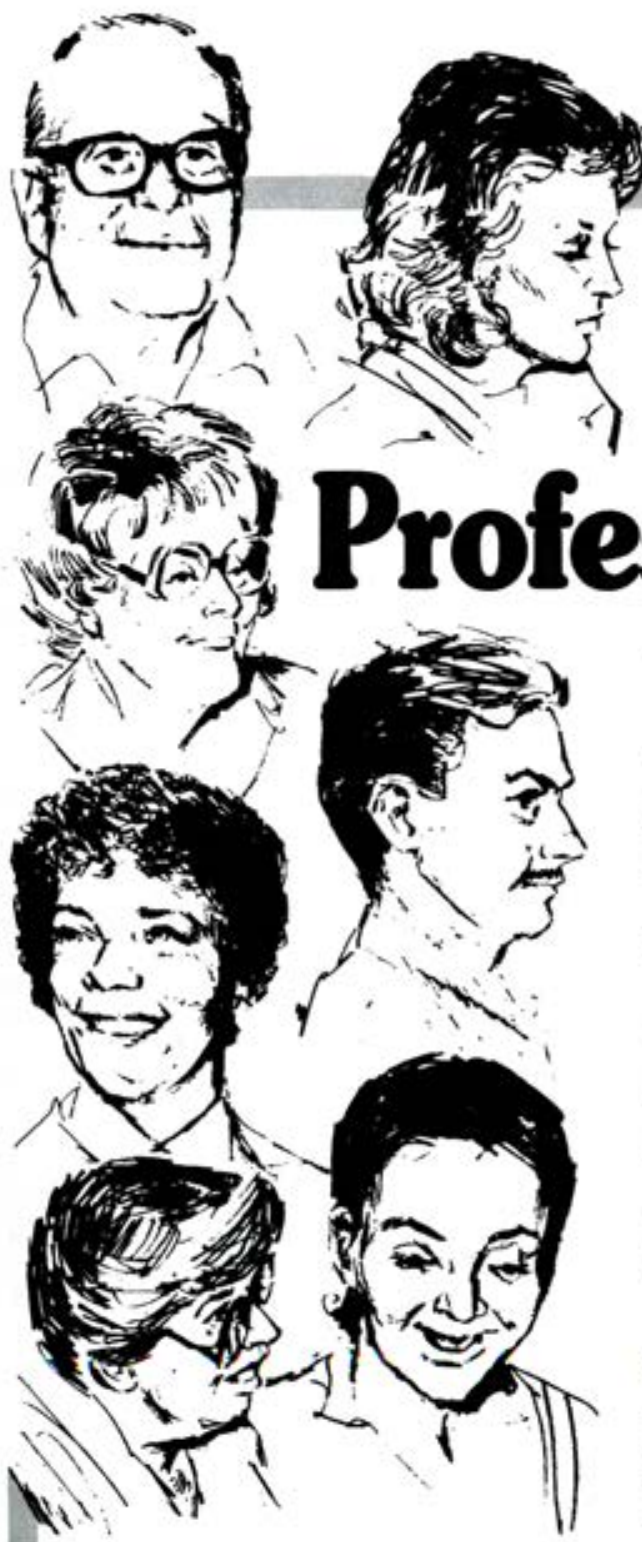

\section{We Are sionals}

We at EBS are dedicated to providing libraries with the fastest service, the best discounts, but above all, the accuracy a library demands.

With all this in your favor you owe it to yourself to try us...

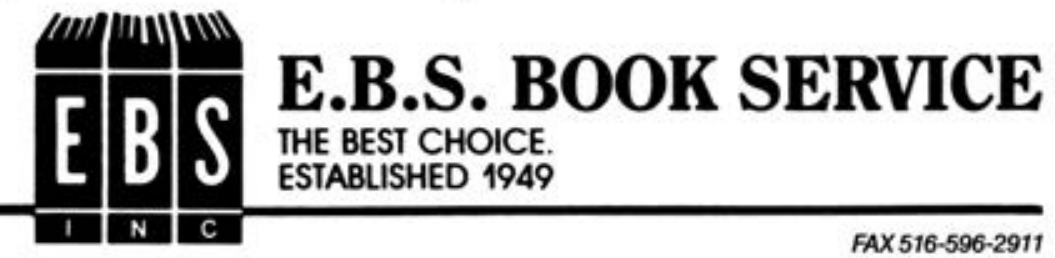

E.B.S. INC. BOOK SERVICE - 290 BROADWAY, LINBROOK, NEW YORK 11563 - 516-593-1207 
cates that the relationship is not a strong one and that faculty evaluations are not reliable predictors of circulation of moderate- and low- use journals. Nancy I. Elder, University of Texas at Austin.

"Whose Money is this Anyway? Budget Allocation and Selection Responsibility in College Libraries," will maintain that the materials budget should be divided by non-departmental categories based on collection growth and service objectives. Sallie H. Barringer, Trinity University.

Papers 8, Friday, April 7, 8:30 a.m. $-9: 30$ a.m., Room 252

"Thunderbolt on Campus: Racist Materials in the Academic Library," will present reasons why libraries should collect materials representing both sides of controversial issues. Carroll $H$. Varner, Northern Illinois University.

"Politically Controversial Monographs: Roles of Publishers, Distributors, Booksellers, Choice Magazine, and Librarians in Acquiring them for American Libraries," will explore the hypothesis that book selection and acquisitions policies and methods fail to acquire many politically controversial monographs. Charles Willett, American Civil Liberties Union of Florida.

Papers 9, Friday, April 7,

10:15 a.m.-11:15 a.m., Room 252

"Latin American Acquisitions: a Continuing Challenge," will discuss how the political, economic and cultural characteristics of Latin Ameri-

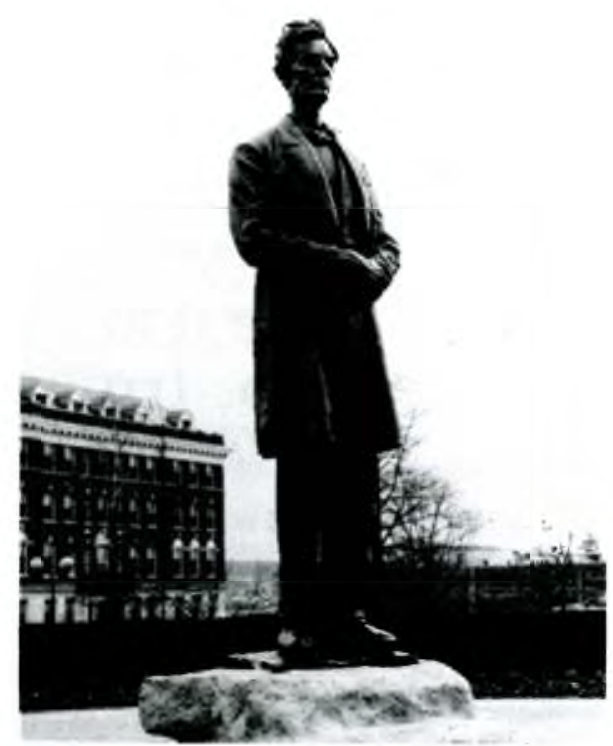

This statue of Abraham Lincoln is one of only two in the U.S. which depicts him without a beard. can countries influence their publishing industries. Joan M. Repp, Bowling Green State University.

"African Imprints in Library Collections: Patterns of Distribution and Reviews," will describe the range of African imprints easily available for acquisition in the United States and reports findings from a study of patterns of holdings in OCLC for African imprints. David L. Easterbrook, University of Illinois at Chicago.

Papers 10, Saturday, April 8,
8:30 a.m.-9:30 a.m., Room 252

"Common Problems, Common Solutions: The Preservation Challenge for Librarians and Archivists," will maintain that librarians and archivists need to recognize the similarity of their positions and seek common solutions. Anne R. Kenney, Cornell University.

"Networking for Disaster Preparedness and Recovery," will propose that major academic and public libraries form networks with other libraries in their regions to provide mutual disaster aid. Sheryl J. Davis, University of California, Riverside.

Papers 11, Saturday, April 8, 9:45 a.m.-10:45 a.m., Room 252

"Custodianship to Conservation: Building on the Preservation Foundations of Our Forebears," will document American academic libraries' turnof-the-century preservation concepts and concerns and demonstrate their influence on present day preservation plans and activities. Barbra Buckner Higginbotham, Brooklyn College of the City University of New York.

"Selection for Preservation: Applications for College Libraries," will report the results of a research study that showed a clear correlation of age and language to use level and physical condition. Charlotte B. Brown, Franklin and Marshall College and Janet Gertz, Pennsylvania State University.

Papers 12, Saturday, April 8,

9:45 a.m. $-10: 45$ a.m., Room 251

"Preserving Our Educational Heritage: The Need to Establish Regional Historical Curriculum Collections," will explain why textbook collections need to be preserved and reports on the creation of a regional research center. Nancy O'Brien, University of Illinois at Urbana-Champaign.

"Overlap and Description of Psychology Collections in Research Libraries," will explore the relationships among the characteristics of psychology monograph collections in research libraries and the title overlap between the collections. Stella Bentley, Case Western Reserve University. 


\section{GENERAL ADMINISTRATION}

\author{
Papers 13, Thursday, April 6, \\ 4:10 p.m.-5: 10 p.m., Room 301
}

"Academic Computing Centers and Libraries: A Path to Convergence," will show that cooperation between libraries and academic computing centers can help each to better meet the service goals of their clients. Michael D. Kathman, St. John's University.

"Academic Libraries and Campus Computing Organizations: Relationships After the First Century," will provide a review of factors and trends that have led academic libraries and campus computing organizations to a closer working relationship and even interdependency. David B. Walch, California Polytechnic State University.

Papers 14, Wednesday, April 5,

2:45 p.m. -4:55 p.m., Room 300

"Identifying Administrative Potential: A Survey," will report survey results of ARL and other research libraries on internal and external library administrator training methods. Margaret E. Galloway, Maurice Fortin and Robert Follet, University of North Texas.

"Management Competencies of Middle Managers in Large Academic Research Libraries," will report the results of a Council on Library Resources funded study of management competencies of middle managers. Martha J. Bailey, Purdue University and Marcy Murphy, Indiana University.

"The Effect of Financial Compensation Policy on the Attitudes of Department Head Librarians at the University of California," will report results of a questionnaire completed by librarians who are department heads at the nine campuses of the University of California. Survey revealed that $68.9 \%$ of the respondents were in favor of additional financial stipends for department heads. Gregor $A$. Preston, University of California, Davis.

Papers 15, Thursday, April 6, 8:30 a.m. $-9: 30$ a.m., Room 250

"The Evaluation Question: Academic Libraries Answer," will investigate the extent to which the effectiveness of service activities is being evaluated; attitudes of academic library administrators; perceived importance of evaluation criteria; and actual participation in evaluation. Sally Ann Strickler, Western Kentucky University.

"Patron Input into Public Service Librarians' Performance Appraisal," will describe a user survey that combined performance appraisal and user evaluation of services. Patricia McCandless, University of Illinois at Urbana-Champaign.

Papers 16, Wednesday, April 5, 2:45 p.m.-3:45 p.m., Room 243
"Interactive Planning in an Ever-Changing Environment," will present an overview of the theory of interactive planning; will describe the implementation of the process as part of the management decision-making system; will critique the method; and will describe the problems and successes in using interactive planning. Joan Giesecke and Kent Hendrickson, University of NebraskaLincoln.

"Policy First: Preparation for Automation," will discuss why policy is critical and will provide examples to show how articulating fundamental automation policies can help the library gain control. Aline Soules, University of Michigan.

\section{Papers 17, Wednesday, April 5,}

3:55 p.m.-4:55 p.m., Room 243

"Academic Libraries: A Matter of Support," will analyze institutional support for academic libraries using two basic criteria: index values for library expenditures from 1976 through 1985 compared to other indexes for consumer, books and periodical prices; and calculating support as expressed as a percentage of the school's educational and general (E\&G) expenditures. John M. Budd, Graduate Library School, University of Arizona.

"Cost Analysis of Library Services at Virginia Polytechnic Institute and State University," will report on a study to determine costs for basic services and to identify which were appropriate to offer in a fee-based service. Lynn Scott Cochrane and Carolyn Warmann, Virginia Polytechnic Institute and State University.

Papers 18, Friday, April 7, 2:50 p.m.-3:50 p.m., Room 302

"Holistic Librarianship: As it Works," will report on the reorganization of the University of Illinois at Urbana-Champaign Library and will examine holistic librarianship from the perspectives of original cataloging, public service and staffing. Barton M. Clark and Karen Havill Bingham, University of Illinois at Urbana-Champaign.

"Who's in Charge Here, Anyway?" will question why so many of us are disgruntled and will answer that in the absence of an Ann Landers for librarians, the answer lies within ourselves. Constance Corey, Arizona State University.

\section{SPECIAL COLLECTIONS}

\author{
Papers 19, Friday, April 7, \\ 2:50 p.m.-3:50 p.m., Room 243
}

"Special Collections and Scholarly Research: A Century of Change," will explore the uses of special collections by scholars and the pressures brought upon the academic research library. Gretchen Lagana, Jane Addams Hull-House. 


\section{NEW FROM SCARECROW}

\section{ADVENTURERS AFLOAT--}

A NAUTICAL BIBLIOGRAPHY:

\section{A Comprehensive Guide}

to Books in English

Ernest W. Toy, Jr.

1193 pp. 2 vol. $1988 \quad 88-31209$

ISBN 0-8108-2189-3 $\$ 89.50$

\section{ILLUSTRATION INDEX VI:}

1982-1986

Marsha C. Appel

541 pp. $1988 \quad 88-18207$ ISBN 0-8108-2146-X $\$ 42.50$

\section{MAPS CONTAINED IN}

THE PUBLICATIONS OF THE

AMERICAN BIBLIOGRAPHY, 1639-

1819: An Index and Checklist Jim Walsh

383 pp. $1988 \quad 88-31916$

ISBN 0-8108-2193-1 $\$ 37.50$

\section{U.S. AND CANADIAN}

BUSINESSES, 1955 TO 1987:

A Bibliography

Priscilla C. Geahigan

601 pp. $1988 \quad 88-30538$

ISBN 0-8108-2186-9 \$52.50

\section{WE SHALL BE HEARD:}

An Index to Speeches by American

Women, 1978-1985

Beverley Manning

626 pp. $1988 \quad 88-6644$

ISBN 0-8108-2122-2 \$62.50

\section{visit our booths at ALA \& ACRL}

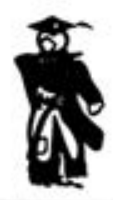

Scarecrow Press

P.O. Box 4167

Metuchen, N. J. 08840

B00-537-7107

89-32
"The Cairns Collection: Women's Writing in Perspective," will describe how the Cairns Collection provides a context for evaluating popular taste and the economics of publishing affecting women writers. Yoonne Schofer, University of WisconsinMadison.

\section{BIBLIOGRAPHIC INSTRUCTION}

\author{
Papers 20, Thursday, April 6, \\ 8:30 a.m. -9:30 a.m., Room 253
}

"Bridges to the Future: A Changing Focus for Bibliographic Instruction and Information Literacy," will discuss the primary concerns about the future of bibliographic instruction as identified by leaders in the field. Lois M. Pausch, University of Illinois at Urbana-Champaign and Mary Pagliero Popp, Indiana University.

"Imperatives for the Second Century: Information Literacy and the Quality of Undergraduate Education in America," will present a rationale for information literacy instruction, will briefly review key articles, and describe Mann Library's efforts and plans. Bill Coons and Jan Kennedy Olsen, Cormell University.

Papers 21, Thursday, April 6, 11:25 a.m.-12:25 p.m., Room 253

"The Collegial Connection: Working With Teaching Faculty to Create a New Course," will present the experiences at Washington State University as a model for academic librarians' involvement in curriculum reform. Paula Elliot and Alice Spitzer, Washington State University.

"Making Real Changes: Course Integrated Instruction and Its Impact, a Case Study," will describe an approach to bibliographic instruction at Cornell where the faculty member and librarian work together on the development of library assignments. Joan Ormondroyd, Cornell University.

Papers 22, Saturday, April 8,

9:45 a.m.-10:45 a.m., Room 253

“Applying Cognitive Methods to Bibliographic Instruction," will recommend that behaviorally oriented workbooks that teach skills be used in conjunction with cognitive techniques that teach concepts. Elizabeth Smith, University of South Florida, Tampa.

"Learning Style: Its Place in Library Instruction," will define learning style in an information environment, will identify characteristics, and will present specific instructional techniques for incorporating learning style theory into library instruction classroom situations. Andrea Wyman, State University of New York at Oswego. 
Papers 23, Thursday, April 6, 4:10 p.m.-5:10 p.m., Room 253

“Students Mentoring Students in Library Information Services for Undergraduates," will demonstrate that student mentors perform well in conducting library tours and in providing end-user search assistance but are less effective in term paper counseling. Terrence Nollen, Linda Parker, Eva Sartori, University of Nebraska-Lincoln.

"Evaluation of Bibliographic Instruction: Directions for the Next Century," will examine the difficulties inherent in constructing effective evaluation tools and will propose a multiple methods model to measure changes in students' abilities to construct and use appropriate research strategies. Nancy O'Hanlon, Ohio State University.

\section{Papers 24, Wednesday, April 5, 2:45 p.m.-3:45 p.m., Room 302}

"Enhancing User Access: Reflections and a Model,"will propose a model for enhancing access to materials in the automated catalog by making the local user the focus of cataloging efforts. Cliff Glaviano, Bowling Green State University.

"Learning to Teach: Using Electronic Innovations in Library Instruction," will show how librarians can take advantage of OPACs, online searching and CD-ROMs in teaching research processes. Mary L. Griffin, Southeast Missouri State University.

\section{ACADEMIC/RESEARCH LIBRARIANSHIP}

\author{
Papers 25, Wednesday, April 5, \\ 2:45 p.m.-3:45 p.m., Room 301
}

"Faculty Status or Academic Status: Must We Choose?" will report on a study of faculty status and will make recommendations for improvement of tenure and promotion documents. Malcolm Germann, Michael Kelly, and Rebecca SchreinerRobles, Wichita State University.

"Faculty Status: Lessons From the Past," will argue that academic librarians are in danger of forgetting the key factors that stimulated the faculty status movement. Gemma Devinney, State University of New York at Buffalo and Mary L. Reichel, University of Arizona.

Papers 26, Wednesday, April 5, 3:55 p.m.-4:55 p.m., Room 301

"Friends and Foes: Academic Libraries Face the Future," will argue that librarians need to be aware of both traditional values and modern technology and use the best of both for their academic libraries. Anne F. Roberts, State University of New York, Albany.

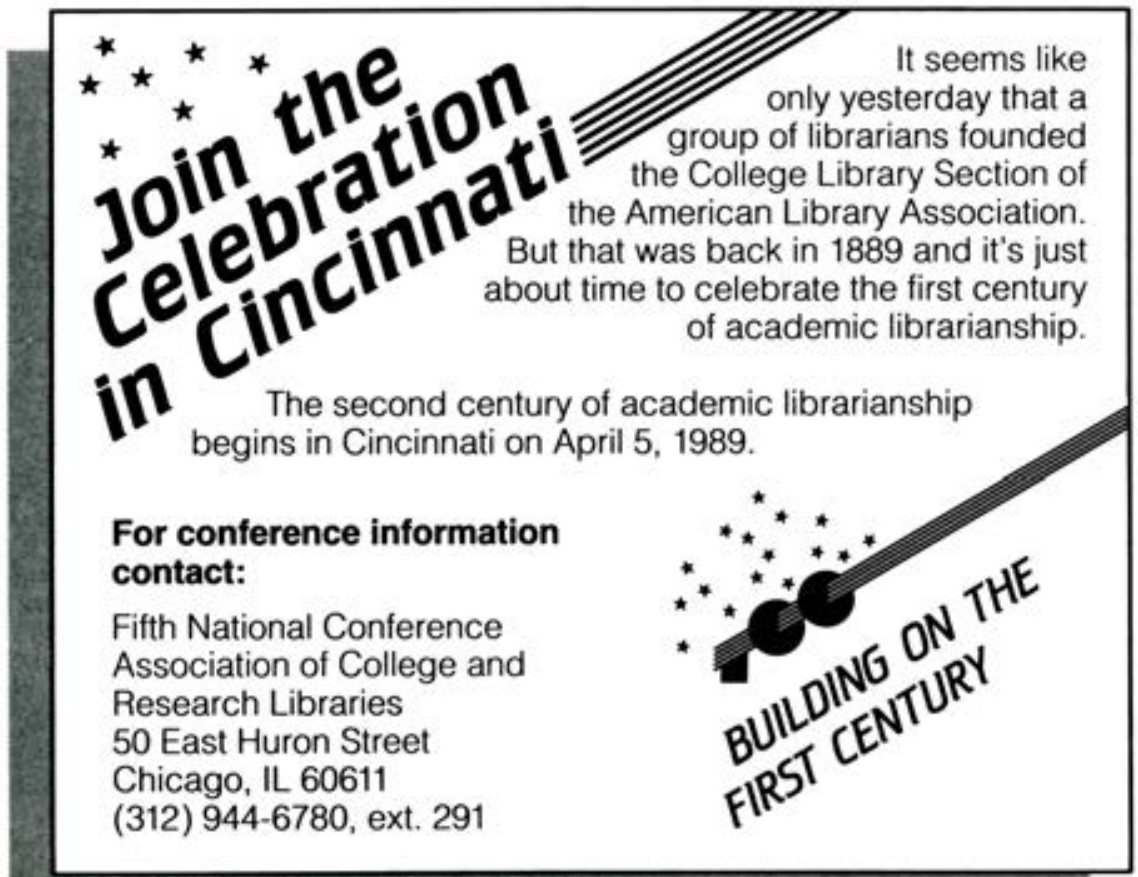


"New Publics for the Academic Library: Technology and Change," will explore changing user paradigms brought about by the implementation of new retrieval and communication technologies. Dennis Brunning, Helen Josephine and Harvey Sager, Arizona State University Libraries.

Papers 27, Wednesday, April 5, 3:55 p.m.-4:55 p.m., Room 302

"Research Librarianship: Services and Support for Faculty Research in the 1980s," will look at programs of specialized reference service to faculty. $E$. Paige Weston and Beverly P. Lynch, University of Illinois at Chicago.

"In the Same Boat Together: Creating an Environment for Research and Publication," will present results from a survey on research activities, the types of support received, the obstacles to doing research and the advantages or disadvantages of creative activity. John A. Camp, David G. Anderson and Anne Page Mosby, Georgia State University.

Papers 28, Thursday, April 6, 11:25 a.m.-12:25 p.m., Room 301

"Academic Librarian Recruitment: Evaluating Past Practices to Help Shape Future Procedures," will examine the aspects of academic librarian recruitment including: position descriptions, letters of reference, resumes, letters of application and interviews. Fred Batt, University of Oklahoma.

"The Role of Practicing Librarians in Library Education," will answer the question, "Who should be actively engaged in designing the library school curriculum of the future?" Gillian M. McCombs, State University of New York, Albany.

\section{PERSONNEL/STAFF}

\author{
Papers 29, Friday, April 7, \\ 2:50 p.m. $-3: 50$ p.m., Room 300
}

"Excellence and the Academic Library Classified Staff," will examine the characteristics of excellent organizations described in works by Thomas Peters and his collaborators-In Search of Excellence, A Passion for Excellence, and Thriving on Chaos, especially as they relate to academic library non-professional staff. Mary K. Bolin, University of Idaho.

"Purposeful 'Schizophrenia': Creative Staffing Through the Use of Split Positions," will describe split positions, joint appointments and dual assignment models as they evolved at a medium-sized ac-

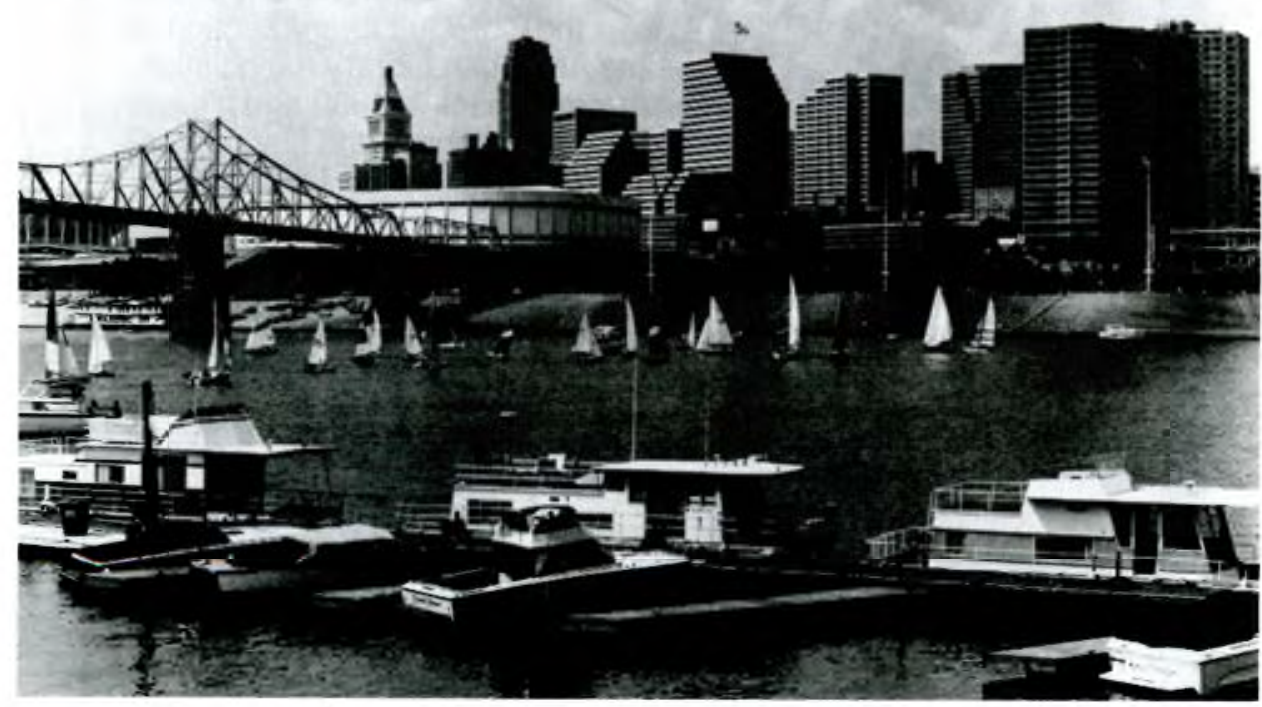

Snaking along Yeatman's Cove Park, the Serpentine Wall edges the skyline of Cincinnati. Riverfront activities abound beginning in early spring and continue through the fall. 
ademic library. Caroline Blumenthal, Sharon Cann, Virginia Moreland and Ralph Russell, Georgia State University.

Papers 30, Saturday, April 8, 8:30 a.m.-9:30 a.m., Room 300

"Institutional Responses to Career Plateaus," will examine the use of leaves, flexible appointments and distributed decision-making to support continued professional learning and growth. Ellen Hoffmann, York University, Ontario.

"A Reexamination of the Career Progression Patterns of Academic Library Administrators," will report on the replication of a 1981 research project that had identified the professional and personal characteristics associated with success in attaining a directorship in an academic library. Barbara B. Moran, University of North Carolina at Chapel Hill.

\section{TECHNOLOGYIAUTOMATION}

\author{
Papers 31, Friday, April 7, \\ 2:50 p.m.-3:50 p.m., Room 301
}

"The Power of the New Microcomputers: Challenge and Opportunity," will discuss the challenge to libraries to provide the same ease of access to information that users have on their own computers. Eric Rumsey, University of Iowa.

"Gender Gap in the Use of Library Technologies: Evidence, Implications, and Intervention," will discuss the gender gap that exists in the use of computers, the implications for library technologies and intervention strategies for addressing the gap. Barton M. Clark, Nancy Anderson, M. Balachandran, Karen Bingham, Suzanne Griffiths, Patricia McCandless, and Lizabeth Wilson, University of Illinois at Urbana-Champaign.

\section{NETWORKING/COOPERATION}

\author{
Papers 32, Saturday, April 8, \\ 8:30 a.m.-9:30 a.m., Room 301
}

"Reluctant Cooperation: Improving Academic and Large Public Library Participation in Multitype Networks," will report findings about academic and large public library participation in multitype networks taken from two research projects. Charles T. Townley, Pennsylvania State University at Harrisburg.

"The User Group Phenomenon," will contend that user groups can be extremely useful both for the vendors and for the participating libraries. Roger L. Presley and Carolyn L. Robison, Georgia State University.
Papers 33, Saturday, April 8 ,

9:45 a.m.-10:45 a.m., Room 301

"Academic Libraries and the Future of Education and Information for Rural Adults: A Model," will report on a project designed to improve the delivery of educational and informational services and resources to people in rural locations. Donna L. Whitson, University of Wyoming.

"Interlibrary Loan: A Window on the Information World?" will argue that although automation has expanded access to information, standards need to be established for regulating turnaround delivery time and alternative delivery methods should be considered. Barbara J. Ford, Trinity University and Paul A. Frisch, Southwest Missouri State University.

\section{THE INTERNATIONAL SCENE IN LIBRARIANSHIP}

\author{
Papers 34, Thursday, April 6, \\ 8:30 a.m. $-9: 30$ a.m., Room 242
}

"An Australian Dime Novel Publisher," will tell the history and overview of Alfred Cecil Rowlandson, publisher of the "Bookstall Series" of paperbacks in Australia. Carol Mills, Riverina-Murray Institute of Higher Education, Australia.

"Building a Foreign Language Collection: China's National Library," will demonstrate how a collection development policy can be used for constructive library planning in developing countries. Special reference will be given to the collection of foreign language materials at the National Library of China, Beijing. Priscilla C. Yu, University of Illinois, Urbana Champaign.

\section{CATALOGING/BIBLIOGRAPHIC CONTROL}

\author{
Papers 35, Saturday, April 8, \\ 8:30 a.m. $-9: 30$ a.m., Room 243
}

"Authority Control: Carrying an Age Old Practice into an Automated Future," will maintain that online authority files create a need to analyze how users approach the catalog and what information they expect it to provide. Barbara Henigman, University of Illinois at Urbana-Champaign.

"Automating Tradition: Use of the Library of Congress MARC Tape Subscriptions for Local Maintenance of Cataloging Data," will describe the University of Georgia Libraries' plan to use the MARC tapes. Greg Anderson, University of Georgia Libraries. 


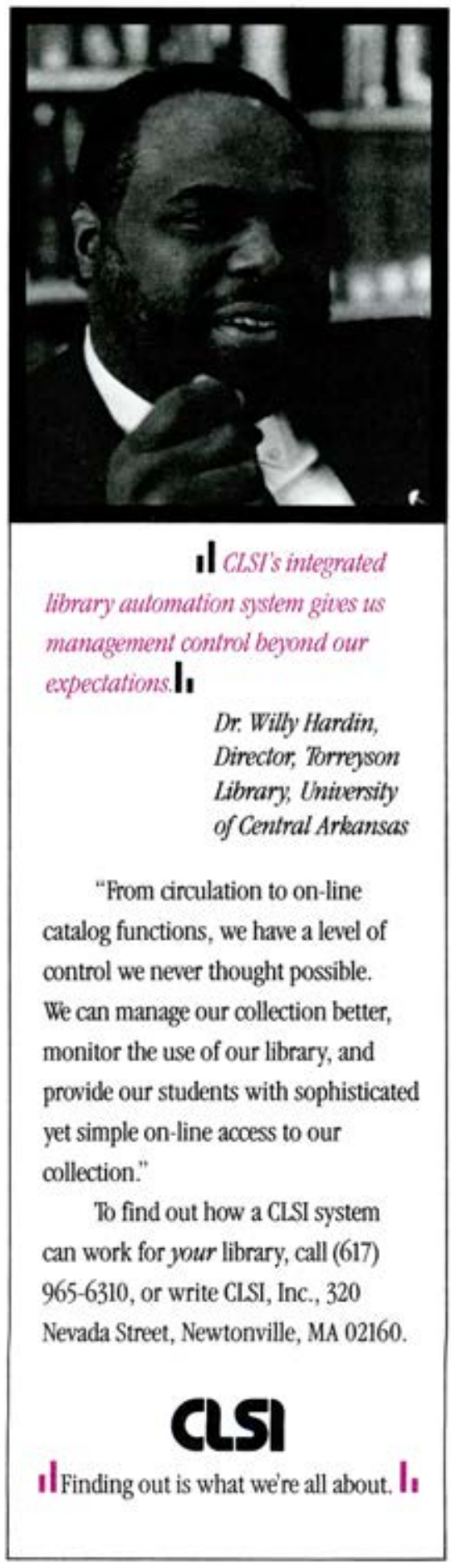

\author{
Papers 36, Thursday, April 6, \\ 4:10 p.m.-5:10 p.m., Room 243
}

"Automated Workstations for Professional Catalogers: A Survey of ARL Libraries," will report the results of a survey of ARL libraries to determine how many libraries had, or soon would have, individual automated workstations for their professional catalogers. Sally A. Rogers, Ohio State University.

"The Relationship Between Cataloging Delay and the Circulation of Books in a Large Research Library," will test the hypothesis that there is an inverse relationship between the length of time a book is backlogged and its usefulness as measured by circulation. David Gleim, University of North Carolina at Chapel Hill.

\section{LIBRARY HISTORY/LIBRARY FACILITIES PLANNING}

\author{
Papers 37, Thursday, April 6, \\ 11:25 a.m.-12:25 p.m., Room 300
}

"The Past Before Us: The Historiography of Academic Librarianship, Past and Future," will identify and evaluate the key historians and their works; will highlight the aspects of librarianship that have been researched; and will propose an agenda for further research. Donald G. Davis, Jr., University of Texas and John Mark Tucker, Purdue University.

"Academic Library Planning: Rationality, Imagination, and Field Theory in the Work of Walter Netsch," will discuss the work of architect Walter Netsch and reviews the implications for design that library planners must face. William $G$. Jones, University of Illinois at Chicago.

\section{INDIVIDUAL PROGRAMS}

\author{
Paper 38, Thursday, April 6, \\ 10:15 a.m.-11:15 a.m., Room 243
}

"Back to the Future: Closing the Periodical Stacks," will report on user satisfaction with the closing of the periodical stacks and the use of a service desk and an automated library system for check-in and check-out. Tjalda Belastock, Bentley College.

Paper 39, Saturday, April 8, 9:45 a.m.-10:45 a.m., Room 300

"Who Are Those Guys? A Report on a Survey of Referees of Library Scholarly Journals," will reveal the experience and qualifications for serving as a referee. Stuart Glogoff, University of Delaware. 
Staying up-to-the-minute with the fast-breaking research that is shaping our future has never been easier with...

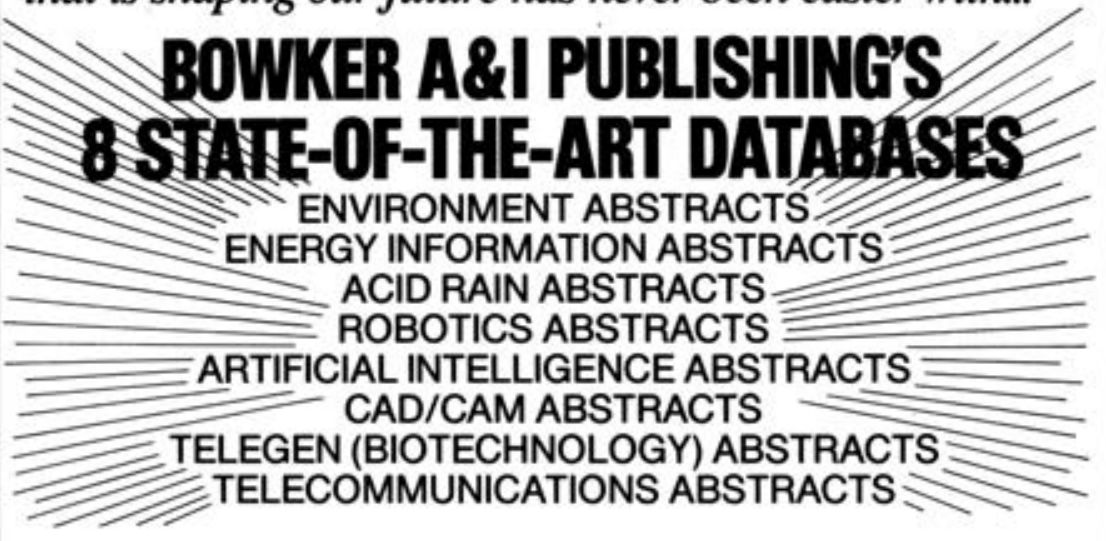

because every month Bowker's eight carefully compiled journals abstract and index thousands of articles on environmental studiex mergy, acid rain", roboticx artificial intelligence, CADVCAM, biofechnology, and telecommenications. The information found in each publication is drawn from over 1.700 international scientific. economic, technical, academic, and trade journals plus seores of leading general-circulation newspapers, magazines, and wire services.

\section{More than just journals.}

Better still, our journals are part of a sophisticated document retrieval system that lets you order comprehensive microfiche collections carrying the full text of ower $80 \%$ of the articles we cite. And you can order microfiche or paper copies of individual articles on a per-document basis as well. In addition, all eight databases are available online from the top online services.

What's more, Bowker A \& I Publishing's journals bring together the "grey" or elusive literature - conference proceedings, government studies, scientific association reports, even patents - that often is neither indexed or available in any readily accessible medium.

So whether you're looking for the latest findings on gene products, ozone depletion. nonconventional fuels, US. acid rain policy. robot locomotion, human-machine interfaces, or any of hundreds of other crucial high-tech issues. don't bury yourself in indexes or burden yourself with serials orders.

"Acad nein in atatracted and insered every rep mones.

Look to Bowker A \& I Publishing to keep you current with the literature. You'll not only make a small research breakthrough yourself...you'll make a big one easier for your patrons, too.

\section{Call Now For a Free Sample Journal!}

TO ORDEA - OA FOR WORE INFORMATION ABOUT OUA INTECRATEO SYSTEM OF MONTRLY JOURMALS, ANMUAL INDEXES, MICAOFCHE, ANO ONUNE DATABASES - CALL TOLLFREE 1-800-521-8110 (BM MY, AK, OR Hi CALL COLUCT 1-212-463-6969).

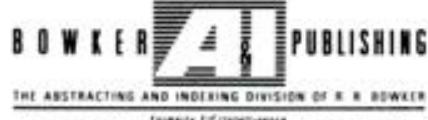

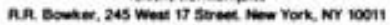

